Kunuz: Journal of Islamic Banking and Finance Vol. 1, No.2 (2021):85-94

Website: http://ejournal.iain-manado.ac.id/index.php/kunuz ISSN 2807-615X (online) ISSN 2807-680X (print)

\title{
IMPLEMENTASI AKUNTANSI MANAJEMEN \\ LINGKUNGAN PADA PERUSAHAAN-PERUSAHAAN \\ DI PT. KAWASAN INDUSTRI MAKASSAR (KIMA)
}

\author{
Kasmawati \\ Fakultas Ekonomi dan Bisnis Islam Universitas Islam Negeri Alauddin Makassar \\ (UIN), Jl. M. Yasin Limpo, Kec. Somba Opu, Kab. Gowa, Sulawesi Selatan, \\ Indonesia, 92113 \\ Email: kasmawatiyobo@gmail.com
}

\section{Fitri Wulandari*}

Fakultas Agama Islam Universitas Cokroaminoto Makassar, J1. Printis

Kemerdekaan No.7 Kec. Tamalanrea, Kota Makassar, Sulawesi Selatan, Indonesia, 90245

Email: dhedewulan28@gmail.com

Salman Ahmad

Fakultas Ekonomi dan Bisnis Islam Universitas Islam Negeri Alauddin Makassar (UIN), Jl. M. Yasin Limpo, Kec. Somba Opu, Kab. Gowa, Sulawesi Selatan, Indonesia, 92113

Email: salman.ahmad@uin-alauddin.ac.id

\section{Syamsul Bahri}

Fakultas Ilmu Budaya Universitas Hasanuddin (UNHAS), Jl. Printis

Kemerdekaan Km 10 Kec. Tamalanrea, Kota Makassar, Sulawesi Selatan, Indonesia, 90245

Email: syamsulbahri@gmail.com

${ }^{*}$ Correspondance

\begin{abstract}
ABSTRAK
Tujuan penelitian ini yaitu untuk mengetahui implementasi akuntansi lingkungan yang ditinjau dari teori Triple Bottom Line sebagaimana yang diungkapkan oleh john elkington bahwa Triple Bottom Line tidak hanya melihat aspek profit (keuntungan) sebagai acuan utama dalam aktivitas perusahaan. Dalam menjawab permasalahan tersebut, penulis menggunakan paradigma kualitatif dengan pendekatan interpretatif. Pendekatan ini merupakan sebuah sistem sosial yang memaknai perilaku secara detail langsung mengobservasi. Interpretif melihat fakta sebagai sesuatu yang unik dan memiliki konteks dan makna yang khusus sebagai esensi dalam memahami sesuatu. Subjek penelitian ini adalah perusahaan-perusahaan di Kawasan Industri Makassar (KIMA) sedangkan informan pada penelitian ini adalah manajer atau karyawan di perusahaan-perusahaan PT. KIMA dalam hal ini yang berperan langsung terhadap lingkungan serta masyarakat yang ada di sekitar PT. KIMA. Hasil penelitian ini menunjukkan bahwa kegiatan-kegiatan akuntansi lingkungan atau CSR pada perusahaan-perusahaan di PT. KIMA terutama PT. Wijaya Karya Beton dan PT. Anugrah Cemerlang Indonesia secara umum telah memenuhi teori atau konsep Triple Bottom Lineyang mencakup pada tiga unsur utama yaitu, profit, people dan planet. Tanggung jawab ekonomi (profit) kedua perusahaan dapat dilihat pada produk-produk yang dihasilkan dari kegiatan operasional
\end{abstract}


Kunuz: Journal of Islamic Banking and Finance Vol. 1, No.2 (2021):85-94

Website: http://ejournal.iain-manado.ac.id/index.php/kunuz ISSN 2807-615X (online) ISSN 2807-680X (print)

bisnisnya. Tanggung jawab lingkungan (planet) kedua perusahaan maupun semua perusahaanperusahaan di PT KIMA dapat dilihat dari program-program CSR bidang lingkungan secara nyata dilakukan untuk menyelamatkan dan melestarikan lingkungan seperti penanaman pohon dan tempat pembuangan limbah kegiatan perusahaan. Tanggung jawab sosial (people) secara nyata dilaksanakan perusahaan-perusahaan PT KIMA melalui aktivitas CSR pada bantuan sarana ibadah dan bantuan sarana kesehatan.

Kata Kunci: Akuntansi; Akuntansi Lingkungan; Teori Triple Bottom Line. 


\section{PENDAHULUAN}

Konsep akuntansi lingkungan mulai berkembang pada tahun 1970-an di Eropa. Di Indonesia sendiri sebagai negara yang sedang berkembang tidak terlepas dari persoalan lingkungan yang semakin hari semakin terasa dampaknya. Konsep ini didasarkan pada tekanan dari lembaga-lembaga bukan pemerintah dan konsep ini menyadarkan masyarakat tentang kesadaran lingkungan agar perusahaanperusahaan menerapkan pengelolaan lingkungan bukan hanya kegiatan industri saja yang diutamakan (Ikhsan, 2008).

"Environmental issues have gained significance in recent years through the dissemination of information on the potentially harmful effects of industrial activities on our environment. Major environmental degradation incidents to datepoint to the need to place controls on commercial activities and to encourage sustainable business practices".

Isu lingkungan dalam beberapa tahun terakhir ini telah mendapatkan perhatian melalui informasi tentang lingkungan yang berpotensi berbahaya dari kegiatan industri. Peristiwa yang terbesar yaitu kerusakan lingkungan yang perlu mendapatkan perhatian dan kontrol pada kegiatan komersial untuk mendorong praktek-praktek bisnis yang berkelanjutan (Lodhia, 1999).

Banyak isu-isu lingkungan yang terjadi di masyarakat luas seperti pemanasan global yang terjadi di Indonesia. Isu-isu lingkungan secara langsung dan tidak langsung telah masuk dalam performa ekonomi suatu usaha/kegiatan maupun organisasi. Peningkatan kebijakan lingkungan usaha dan informasi keuntungan bagi investor maupun pelaku bisnis berdasarkan perlindungan lingkungan produk, merupakan salah satu contoh yang bisa diketengahkan saat Keutamaan penggunaan konsep akuntansi lingkungan bagi perusahaan adalah kemampuan untuk minimalisir persoalan-persoalan lingkungan yang dihadapinya. Banyak perusahaan besar industri dan jasa yang kini menerapkan akuntansi lingkungan. Tujuannya adalah meningkatkan efisiensi pengelolaan lingkungan dengan melakukan penilaian kegiatan lingkungan dari sudut pandang biaya (environmental costs) dan manfaat atau efek (economic benefit) (Ikhsan, 2008).

Berdasarkan UU No. 23 tahun 1997 mengenai Pengelolaan Lingkungan Hidup beserta peraturan pelaksanaannya, kinerja pengelolaan lingkungan wajib diungkapkan dan disampaikan oleh setiap orang/penanggung-jawab kegiatan. Pada umumnya informasi yang disampaikan hanyalah mengenai pengendalian pencemaran udara, sedangkan informasi kinerja pengelolaan lingkungan lainnya secara rinci hanya disampaikan kepada instansi lingkungan hidup. Sehingga bagi masyarakat yang ingin mengetahuinya harus mengakses sendiri (Nuswantara, 2008).

Hal ini pula dijelaskan dalam pengertian teori Triple Bottom Line menurut (Lako, 2011) bahwa pelaporan yang menyajikan informasi tentang kinerja ekonomi (profit), lingkungan (planet), dan sosial (people) dari suatu entitas perusahaan. Tujuannya adalah agar stakeholder bisa mendapat informasi yang lebih komprehensif untuk menilai kinerja, risiko, dan prospek bisnis, serta kelangsungan hidup suatu perusahaan. 


\section{Kunuz: Journal of Islamic Banking and Finance Vol. 1, No.2 (2021):85-94 \\ Website: http://ejournal.iain-manado.ac.id/index.php/kunuz ISSN 2807-615X (online) ISSN 2807-680X (print)}

Akuntansi sebagai calculate science juga menerapkan atau memasukkan lingkungan dalam implementasi ilmunya. Hal ini berkaitan dengan keterbukaan perusahaan untuk mengungkapkan informasi lingkungan sebagai dampak dari aktivitas industri atau bisnis mereka. Akuntansi lingkungan (Environmental Accounting) adalah istilah yang berkaitan dengan dimasukkannya biaya lingkungan (environmental costs) ke dalam praktek akuntansi perusahaan atau lembaga pemerintah. Biaya lingkungan adalah dampak (impact) baik moneter maupun nonmoneter yang harus dipikul sebagai akibat dari kegiatan yang mempengaruhi kualitas lingkungan (Gunawan, 2012). Akuntansi Lingkungan Hidup juga merupakan metodologi untuk menilai biaya dan manfaat dari sebuah kegiatan lingkungan untuk mengurangi dampak lingkungan. Hasil akuntansi ini digunakan oleh para pimpinan perusahaan untuk membuat keputusan yang berkaitan dengan perbaikan lingkungan. Dalam Keputusan Menteri Negara Lingkungan Hidup No. 42 tahun 1994 (Kartikasari, 2012).

Akuntansi lingkungan merupakan sarana untuk melaporkan operasional suatu lembaga (negara/kota/perusahaan/organisasi) yang dikaitkan dengan lingkungan. Tujuannya adalah memberikan informasi mengenai kinerja operasional perusahaan yang berbasis pada perlindungan lingkungan. Perusahaan yang hanya mementingkan profit dan tidak peduli pada lingkungan akan terkena externalities berupa boikot dari konsumen, protes dari aktivis lingkungan hidup, protes dari pemegang sahamnya dan mungkin dari karyawannya sendiri. Walaupun pada kenyataannya ada beberapa perusahaan yang merekayasa laporan keuangan supaya terlihat ikut serta dalam perlindungan lingkungan (Martusa, 2009).

Melihat ruang lingkup perusahaan yang semakin luas yaitu dimulai dari pemetaan, eksplorasi, ekploitasi sumber energi dan mineral serta penelitian bahan galian, pengolahan hasil tambang dan mungkin sampai penggunaan bahan baku dalam pembuatan pupuk dan beton yang mengakibatkan gangguan pada lingkungan, maka perlu adanya perhatian dan pengendalian terhadap pencemaran lingkungan dan perubahan keseimbangan ekosistem, agar sektor yang sangat vital untuk pembangunan ini dapat dipertahankan kelestariannya.

Dalam al-Qur'an pun dijelaskan mengenai kerusakan lingkungan yang disebabkan oleh manusia yang Allah berfirman,

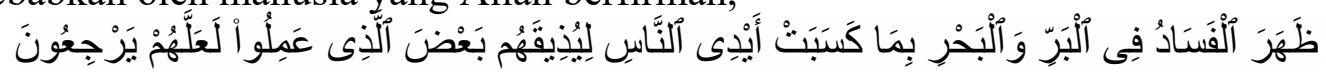

Terjemahnya:

"Telah nampak kerusakan di darat dan di laut disebabkan karena perbuatan tangan manusia, supaya Allah merasakan kepada mereka sebahagian dari (akibat) perbuatan mereka, agar mereka kembali (ke jalan yang benar)" (QS.Ar-Rum: 30: 743)

Ayat di atas menjelaskan bahwa kerusakan yang terjadi di alam semesta ini baik yang ada di darat ataupun di laut penyebab utamanya adalah karena perbuatan manusia. Bencana yang datang silih berganti mengiringi kerusakan alam yang semakin parah ini bukan salah siapapun, bukan fenomena alam, melainkan perbuatan manusia sendiri yang tidak bijak mengelolanya. Misalnya bencana banjir yang sering merenggut banyak nyawa manusia dan berbagai kerusakan yang disebabkan oleh perbuatan manusia yang menebang hutan sembarangan sehingga terjadi kegundulan dan tidak menanam pohon kembali serta tidak mengimbangi 
ekosistem yang ada.

Pada era pemanasan global ini, lingkungan menjadi masalah krusial. Penerapan akuntansi lingkungan pada laporan keuangan pada perusahaanperusahaan perlu mendapat perhatian khusus. Hadirnya akuntansi lingkungan merupakan salah satu wujud dan kesadaran akan pentingnya menerapkan kepedulian terhadap lingkungan mengingat lingkungan punya kontribusi besar terhadap kelangsungan hidup bukan hanya bagi perusahaan tapi manusia secara umum. Namun yang menjadi permasalahan bagaimana kontribusi akuntansi lingkungan ini terhadap perusahaan mengingat perusahaan sangat identik dengan pengrusakan lingkungan. Permasalahan lingkungan yang ditimbulkan oleh kegiatan perusahaan sangat kompleks. Sehingga tidak heran dikatakan bahwa perusahaan selalu menimbulkan kerusakan (Hasan \& Azis, 2018). Lantas apakah dengan hadirnya akuntansi lingkungan ini dapat menjadi solusi atas kerusakan yang selama ini ditimbulkan oleh perusahaan ataukah ini hanya akan menjadi sebuah jalan bagi para oknum tertentu untuk melegalkan kegiatan-kegiatan perusahaan meskipun dengan berbagai konsekuensi lingkungan yang ditimbulkan.

Pada era pergerakan perusahaan ke arah green company, kalangan industri tidak hanya dituntut untuk mengolah limbahnya semata, tetapi tuntutan masyarakat konsumen lebih jauh lagi yaitu agar proses produksi suatu barang mulai dari pengambilan bahan baku sampai ke pembuangan suatu produk setelah dikonsumsi (digunakan) tidak merusak lingkungan. Hal ini diperkuat lagi dengan adanya ISO yang memuat kriteria lingkungan di dalam standar produksi suatu barang (Idris, 2012).

Permasalahan-permasalahan sosial lingkungan, setidaknya didorong oleh munculnya ajaran kapitalis. Ajaran ini mendorong perusahaan untuk selalu mencari cara agar dapat berproduksi secara efisien. Teori-teori konsumsi memiliki asumsi bahwa konsumen berupaya untuk memaksimalkan utilitasnya. Demikian pula perusahaan, entrepreneur termotivasi untuk memaksimalkan pembagian residualnya, yaitu profit. Hal ini tampak pula dalam dua konsep akuntansi yang cukup populer, yaitu konsep proprietori (proprietary) dan konsep entitas (entity). Konsep proprietori memandang bahwa perusahaan dimiliki hanya oleh pemilik, serangkaian partner, atau sejumlah pemegang saham. Oleh karena itu aktiva perusahaan dipandang sebagai kekayaan pihak-pihak tersebut dan kewajiban perusahaan adalah kewajiban mereka. Konsep entitas, sebagaimana konsep proprietori, memandang pemegang saham dan kreditor adalah pihak di luar perusahaan yang mempunyai kepentingan terhadap operasi perusahaan. Kedua konsep tersebut memberikan implikasi bahwa bisnis semata-mata merupakan entitas yang berorientasi keuangan karena pihak yang terlibat di dalamnya memiliki kepentingan akan hasil operasi keuangan (Nuswantara, 2008).

Upaya pengelolaan lingkungan dengan mengacu pada prinsip ramah lingkungan sangat diperlukan oleh perusahaan. salah satu perusahaan yang menerapkan prinsip ramah lingkungan tersebut adalah perusahaan-perusahaan PT. KIMA. Salah satu anak perusahaan yang ramah lingkungan dalam Kawasan Industri Makassar adalah PT. Wijaya karya Beton (PT. WIKA Beton) yang khusus bergerak di industri beton pracetak serta Anugrah Cemerlang Indonesia yang khusus bergerak di industri pupuk organik. 


\section{Kunuz: Journal of Islamic Banking and Finance Vol. 1, No.2 (2021):85-94 \\ Website: http://ejournal.iain-manado.ac.id/index.php/kunuz ISSN 2807-615X (online) ISSN 2807-680X (print)}

\section{METODE PENELETIAN}

Pada penelitian ini, peneliti menggunakan paradigma kualitatif dengan pendekatan Interpretif yang bertempat di perusahaan-perusahaandi kawasan Industri Makassar (KIMA). Peneliti juga melakukan observasi dan wawancara langsung kepada pihak yang terlibat pada lingkungan perusahaan. Adapun yang menjadi subjek penelitian adalah karyawan 1 (satu) orang, kepala RT 1 (satu) orang, dan masyarakat yang berdomisili di lokasi penelitian 1 (satu) orang. Adapaun data data primer merupakan data yang diperoleh langsung dari hasil dokumentasi dan wawancara oleh peneliti terhadap objek penelitian. Data sekunder merupakan data yang diperoleh dari hasil dokumentasi yang dilakukan oleh objek penelitian maupun dari pihak lain yang memiliki relevansi dengan penelitian yang dilakukan.

Analisis dilakukan dengan membaca laporan pengungkapan tanggungjawab sosial Kawasan Industri Makassar, lalu dikaitkan dengan hasil depth interview dan observasi yang berlandaskan pada teori Triple Bottom Line yaitu: profit, planet dan people. Dengan teori Triple Bottom Line tersebut peneliti dapat menilai apakah hasil pertanggungjawaban yang diungkapkan telah sesuai dengan teori tesebut, dimana faktor penilai yang digunakan merupakan hasil depth interview serta observasi, yang dikaitkan dengan teori Triple Bottom Line sebagai dasar teori dari penelitian ini.

\section{HASIL DAN PEMBAHASAN}

Istilah teori Triple Bottom Line dipopulerkan pertama kali oleh John Elkington (1997) di dalam bukunya "Cannibals With forks, The Triple Bottom Line of Twentieth Century Business" memberi pandangan perusahaan yang ingin berkelanjutan haruslah memperhatikan "3P". Selain mengejar keuntungan (profit), perusahaan juga mesti memperhatikan dan terlibat pada pemenuhan kesejahteraan masyarakat (people) dan turut berkontribusi dalam menjaga kelestarian lingkungan (planet) (Hasanah, 2020). Teori ini menjadi salah satu latar belakang berdirinya KIMA yang diungkapkan dalam laporan pengelolaan dan pemantauan KIMA.

Pembangunan berkelanjutan PT KIMA tidak hanya dituntut untuk memperhatikan keuntungan ekonomi semata, namun juga memperhatikan aspek lainnya yakni aspek sosial dan aspek ekologi (laporan pengelolaan dan pemantauan PT KIMA tahun 2013 h. 4).

Berdasarkan latar belakang tersebut, dapat digambarkan bahwa perusahaanperusahaan di PT KIMA menyadari dan meyakini bahwa ekonomi, sosial dan lingkungan merupakan bagian penting dari pembangunan berkelanjutan perusahaan.Hal ini sesuai dengan teori Triple Bottom Line yang tidak hanya memperhatikan. keuntungan perusahaan saja tapi memperhatikan masyarakat dan lingkungan yang ada disekitar perusahaan.

Keseimbangan Triple Bottom Line merupakan suatu upaya yang sungguhsungguh untuk bersinergi dengan tujuan pembangunan berkelanjutan yang secara konsisten mendorong keseimbangan ekonomi, sosial dan lingkungan (Nurhidayat et al., 2020). Idealnya, tentu saja perusahaan melakukan seluruh kegiatan Triple Bottom Line bagi para stakeholdernya. Namun, hal yang terpenting sebenarnya perusahaan melakukan CSR dengan menekankan pada lingkungan dan 


\section{Kunuz: Journal of Islamic Banking and Finance Vol. 1, No.2 (2021):85-94 \\ Website: http://ejournal.iain-manado.ac.id/index.php/kunuz ISSN 2807-615X (online) ISSN 2807-680X (print)}

penbangunan keberlanjutan (sustainable development).

Menurut Yuswohady bahwa ide Triple Bottom Line ini mencoba menempatkan upaya pemberdayaan masyarakat dan pelesatrian lingkungan pada titik sentral dari keseluruhan strategi perusahaan bukan periferal, bukan tempelan, bukan kosmetik (Nurhidayat et al., 2020). Conventional wisdom yang selama ini ada mengatakan: tumpuk profit sebanyak-banyaknya, lalu dari profit yang menggunung itu sisihkan sedikit saja untuk kegiatan sosial dan pelestarian lingkungan.

Penelitian ini berfokus pada indikator Triple Bottom Line khusus aspek lingkungan. Namun, karena aspek lingkungan, ekonomi, sosial tidak bisa dipisahkan sebagaimana dikemukan oleh John Elkington dalam Lako (Lako, 2011) bahwa agar bisnis perusahaan bisa tumbuh secara berkelanjutan hanya ada satu pilihan, yaitu menyeleraskan pencapaian kinerja laba (profit) dengan kinerja sosial (people) dan kinerja lingkungan (planet) secara berkesinambungan, maka penulis menguraikan implementasi aspek-aspek sebagai berikut:

1. Ekonomi (profit)

Ekonomi menjadi tujuan utama dan terpenting dalam setiap kegiatan usaha. Tidak heran bila fokus utama dari seluruh kegiatan dalam perusahaan adalah mengejar profit dan mendongkrak harga saham setinggi-tingginya. Karena inilah bentuk tanggung jawab ekonomi yang paling esensial terhadap pemegang saham. Aktivitas yang dapat ditempuh untuk mendongkrak profit antara lain dengan meningkatkan produktivitas dan melakukan efiisensi biaya. Peningkatan produktivitas bisa diperoleh dengan memperbaiki manajemen kerja mulai penyederhanaan proses, mengurangi aktivitas yang tidak efisien, menghemat waktu proses dan pelayanan. Sedangkan efisiensi biaya dapat tercapai jika perusahaan menggunakan material sehemat mungkin dan memangkas biaya serendah mungkin.

Kontribusi perusahaan dalam bidang ekonomi juga dapat ditunjukkan dengan peningkatan kesejehateraan terhadap masyarakat sekitar perusahaan. Kesejahteraan untuk pihak internal harus dibarengi dengan kesejateraan untuk pihak eksternal (dalam hal ini masyarakat) (Kasmawati, 2014). Hal ini pun disadari oleh KIMA dengan berkontribusi terhadap masyarakat dengan jalan menumbuh kembangkan usaha-usaha di masyarakat sekitar seperti membuka berbagai usaha di bidang penjualan makanan, sebagaimana dapat dilihat secara jelas dalam laporan pengelolaan dan pemantauan KIMA.

KIMA membawa dampak yang sangat positif di bidang ekonomi, dalam hal ini menyerap tenaga kerja yang cukup banyak, sehingga dapat mengurangi pengangguaranyang hingga saat ini merupakan masalah nasional yang belum terpecahkan, meningkatkan nilai ekonomi tanah di lokasi tersebut, menumbuh kembangkan usaha-usaha di masyarakat sekitar seperti membuka berbagai usaha di bidang penjualan di bidang makanan, usaha wartel, tempat kost, dan sebagainya. (Laporan Pengelolaan dan Pemantauan KIMA hal. 4)

Melihat dari pernyataan di atas dapat disimpulkan bahwa bukan hanya perusahaan yang mendapatkan keuntungan tetapi masyarakat yang ada di sekitar kawasan mendapatkan keuntungan pula karena bisa bekerja dalam perusahaanperusahaan kawasan tersebut. 


\section{Kunuz: Journal of Islamic Banking and Finance Vol. 1, No.2 (2021):85-94 \\ Website: http://ejournal.iain-manado.ac.id/index.php/kunuz ISSN 2807-615X (online) ISSN 2807-680X (print)}

Peryataan di atas sangat terkait dengan salah satu teori yang mendasari sebuah perusahaan melakukan CSR yaitu, teori Legitimasi. Pernyataan tersebut sejalan dengan apa yang diungkapkan Deegan et. al. yang menyatakan kontrak sosial yang berkaitan dengan license to operate, digunakan untuk menjelaskan tentang anggapan dari masyarakat mengenai bagaimana seharusnya sebuah perusahaan beroperasi. Khususnya bila mengenai terancamnya hidup sebuah perusahaan akibat masyarakat menganggap bahwa perusahaan telah melanggar kontrak sosial. Kesimpulan yang dapat ditarik ialah perusahaan-perusahaan di kawasan industri Makassar dalam melaksanakan CSR juga memberikan perhatian kepada seluruh pihak yang berkepentingan artinya perusahaan-perusahaan di kawasan industri Makassar tidak sekedar peduli pada pemegang saham tetapi juga kepada semua pihak yang berkepentingan untuk tetap menjamin terjaganya investasi sosial guna mendapatkan license to operate dari semua orang yang berkepentingan.

2. Sosial

People atau masyarakat merupakan stakeholders yang sangat penting bagi perusahaan, karena dukungan masyarakat sangat diperlukan bagi keberadaan, kelangsungan hidup, dan perkembangan perusahaan. Maka dari itu perusahaan perlu berkomitmen untuk berupaya memberikan manfaat sebesar-besarnya kepada masyarakat.

Berdasarkan laporan pelaksanaan Corporate Social Responsibility PT. KIMA, perusahaan yang berlokasi di Jl. Perintis Kemerdekaan ini telah melakukan berbagai kegiatan yang dapat menyentuh kebutuhan masyarakat yakni memberikan bantuan sarana ibadah dan bantuan kesehatan. Operasi perusahaan berpotensi memberi dampak kepada masyarakat (Lindawati \& Puspita, 2015). Oleh karena itu perusahaan perlu untuk melakukan berbagai kegiatan yang dapat menyentuh kebutuhan masyarakat.

Selama periode Juli sampai dengan desember 2013, PT KIMA telah melakukan berbagai hal diantaranya adalah 'Bantuan sarana ibadah sebesar Rp 14.950.000, bantuan sarana kesehatan sebesar Rp 6.850.000' (laporan pelaksanaan CSR PT KIMA tahun 2013 hal. 40)

Dari pernyataan di atas bahwa Pelaksanaan CSR yang dilakukan perusahaan-perusahaan PT KIMA belum sepenuhnya terlaksana dengan baik karena dalam pelaksanaannya didasarkan pula pada keputusan yang tidak hanya berdasarkan faktor keuangan, seperti keuntungan deviden semata namun juga berdasarkan konsekuensi sosial dan lingkungan demi kelancaran operasional perusahaan saat ini maupun yang akan datang.

3. Lingkungan

Planet atau Lingkungan adalah sesuatu yang terkait dengan seluruh bidang dalam kehidupan manusia. Hubungan perusahaan dengan lingkungan adalah hubungan sebab akibat, dimana jika perusahaan merawat lingkungan maka lingkungan akan memberikan manfaat kepada perusahaan. Sudah kewajiban perusahaan untuk peduli terhadap lingkungan hidup dan berkelanjutan keragaman hayati. Misalnya, penghijauan lingkungan hidup, perbaikan pemukiman, serta pengembangan pariwisata (ekoturisme) dalam (syuhada 2012:27). Namun sebagiaan besar dari manusia masih kurang peduli terhadap lingkungan sekitar. Hal ini disebabkan karena tidak ada keuntungan langsung yang bisa diambil 
didalamnya.

Keuntungan merupakan inti dari dunia bisnis dan itu merupakan hal yang wajar (Nurbaiti \& Bambang, 2017). Maka, manusia sebagai pelaku industri hanya mementingkan bagaimana menghasilkan uang sebanyak-banyaknya tanpa melakukan upaya apapun untuk melestarikan lingkungan. Padahal dengan melestarikan lingkungan, manusia justru akan memperoleh keuntungan yang lebih, terutama dari sisi kesehatan, kenyamanan, di samping ketersediaan sumber daya yang lebih terjamin kelangsungannya.

Berdasar hal tersebut diharapkan keberadaan Perusahaan PT Wijaya karya Beton dan Anugrah Cemerlang Indonesia tidak hanya bermanfaat bagi para pemegang saham (shareholders), tetapi juga kepada pemangku kepentingan (stakeholders) yang lebih luas yaitu masyarakat dan lingkungan. Dengan kata lain, PT Wijaya Karya Beton dan Anugrah Cemerlang Indonesia berusaha untuk memaksimalkan laba perusahaan (profit) selaras dengan tujuan untuk memberikan manfaat yang sebesar-besarnya bagi masyarakat (people), dan lingkungan (planet). PT Wijaya karya Beton dan Anugrah Cemerlang Indonesia meyakini bahwa dengan pendekatan yang menyeluruh ini akan mendukung tercapainya tujuan pembangunan yang berkelanjutan (sustaibable development), yaitu kegiatan pembangunan yang dilakukan untuk memenuhi kebutuhan generasi sekarang tanpa mengorbankan kepentingan generasi mendatang.

\section{KESIMPULAN}

Kegiatan-kegiatan CSR yang dilaksanakan oleh perusahan-perusahaan PT KIMA secara umum telah memenuhi teori atau konsep Triple Bottom Line yang mencakup pada tiga unsur utama yaitu, profit, people dan planet serta aspek keberlanjutan program yang dinilai. Prinsip pembangunan keberlanjutan yang menyebutkan bahwa manusia dan lingkungan bagian yang integral sebuah roda perputaran bisnis perusahaan. Tanggung jawab ekonomi (profit) kedua perusahaan dapat dilihat pada produk-produk yang dihasilkan dari kegiatan operasional bisnisnya. Tanggung jawab lingkungan (planet) kedua perusahaan maupun semua perusahaan-perusahaan di PT KIMA dapat dilihat dari program-program CSR bidang lingkungan secara nyata dilakukan untuk menyelamatkan dan melestarikan lingkungan seperti penanaman pohon dan tempat pembuangan limbah kegiatan perusahaan. Tanggung jawab sosial (people) secara nyata dilaksanakan perusahaanperusahaan PT KIMA melalui aktivitas CSR pada bantuan sarana ibadah dan bantuan sarana kesehatan.Tanggung jawab sosial (people) secara nyata dilaksanakan perusahaan-perusahaan PT KIMA melalui aktivitas CSR pada bantuan sarana ibadah dan bantuan sarana kesehatan.

\section{DAFTAR PUSTAKA}

Gunawan, E. (2012). Tinjauan Teoritis Biaya Lingkungan Terhadap Kualitas Produk dan Konsekuensinya Terhadap Keunggulan Kompetitif Perusahaan. Jurnal Ilmiah Mahasiswa Akuntansi, 1(2), 47-50.

Hasan, M., \& Azis, M. (2018). Pembangunan Ekonomi dan Pemberdayaan Masyarakat: Strategi Pembangunan Manusia dalam Perspektif Ekonomi Lokal. CV. Nur Lina Bekerjasama dengan Pustaka Taman Ilmu. 
Kunuz: Journal of Islamic Banking and Finance Vol. 1, No.2 (2021):85-94

Website: http://ejournal.iain-manado.ac.id/index.php/kunuz ISSN 2807-615X (online) ISSN 2807-680X (print)

Hasanah, U. (2020). Triple Bottom Line Theory dalam Perspektif Corporate Social Responsibility. Majalah Keadilan, 19(1), 11-24.

Idris. (2012). Akuntansi Lingkungan Sebagai Instrumen Pengungkapan Tanggung Jawab Perusahaan Terhadap Lingkungan di Era Green Market. Jurnal Economic, 2(2), 1-10.

Ikhsan, A. (2008). Akuntansi lingkungan dan pengungkapannya. Yogyakarta: Graha Ilmu.

Kartikasari, L. (2012). Niat akuntan dan akuntansi lingkungan. Universitas Islam Sultan Agung, 2012.

Kasmawati, K. (2014). Implementasi Akuntansi Lingkungan Berdasarkan Teori Triple Bottom Line pada Perusahaan-Perusahaan di Kawasan Industri Makassar. Universitas Islam Negeri Alauddin Makassar.

Lako, A. (2011). Dekonstruksi CSR dan Reformasi Paradigma Bisnis dan Akuntansi. In Jakarta: Erlangga.

Lindawati, A. S. L., \& Puspita, M. E. (2015). Corporate Social Responsibilty: Implikasi Stakeholder dan Legitimacy Gap dalam Peningkatan Kinerja Perusahaan. Jurnal Akuntansi Multiparadigma, 6(1), 157-174.

Lodhia, S. K. (1999). Environmental accounting in Fiji: An extended case study of the Fiji Sugar Corporation. Available at SSRN 290452.

Martusa, R. (2009). Peranan Environmental Accounting terhadap Global Warming. Jurnal Akuntansi, 1(2), 164-179.

Nurbaiti, S. R., \& Bambang, A. N. (2017). Faktor-Faktor yang Mempengaruhi Partisipasi Masyarakat dalam Pelaksanaan Program Corporate Social Responsibility (CSR). Proceeding Biology Education Conference, 14(1), 224228.

Nurhidayat, E., Junaid, A., \& Kamase, J. (2020). Penerapan Akuntansi Lingkungan Berdasarkan Triple Bottom Line Pada Rsud HM Djafar Harun Kabupaten Kolaka Utara. Jurnal Ilmu Akuntansi, 2(2), 38-80.

Nuswantara, D. A. (2008). Akuntansi Lingkungan: Antara Mandatory dan Voluntary. Jurnal Pelangi Ilmu,(Online), 2(2). 